\title{
A note on metabolisable energy value of molasses for ostriches
}

\author{
S.C. Cilliers' ${ }^{1}$ and J. Sales ${ }^{2 *}$ \\ 'Camelus Feeds LTD, P. O. Box 468, Oudtshoorn, 6620, South Africa \\ 'Department of Animal Science, University of Stellenbosch \\ Private Bag XI, Matieland, 7602, South Africa
}

(Received 3 January 1999; accepted 9 January 1999)

\begin{abstract}
Metabolisable energy value of sugar canc molasses was determined in a balance study with seven month old ostriches. A true metabolisable energy value, corrected for zero nitrogen $(\mathrm{N})$ retention $\left(\mathrm{TME}_{\mathrm{N}}\right.$ ), of $7.77 \mathrm{MJ} / \mathrm{kg}$ on an air dry basis was calculated. Literature stated values of 8.3 and $9.8 \mathrm{MJ} / \mathrm{kg}$ on a $75 \%$ dry matter basis for poultry and pigs, respectively. It seems that inclusion level, as found with ruminants, might have an influence on energy value of molasses for ostriches. The energy value determined for molasses could be add to the list of feedstuffs already evaluated for ostriches.
\end{abstract}

KEY WORDS: ostriches, molasses, metabolisable energy

\section{INTRODUCTION}

It is common practice to extrapolate nutritional results obtained with poultry to develop nutritional strategies for ostriches, resulting in the application of unrealistic values (Cilliers et al., 1999). Higher metabolisable energy values than for poultry were reported for most ingredients commonly used in ostrich feeding (Cilliers et al., 1994, 1997, 1999), partly attributed to fermentation of dietary fibre in the ostrich.

Sugar cane molasses is probably the most widely known and applied by-product of the sugar industry. Due to the variation in moisture content of molasses a "standardised" molasses with a moisture content of approximately $25 \%$ is marke-

\footnotetext{
* Corresponding author
} 
ted in South Africa'. Although molasses is associated with ruminants, it can also be used in monogastric feeding (Van Niekerk, 1981). The present study was conducted to determine the energy value of molasses for ostriches.

\section{MATERIAL AND METHODS}

Twenty four African Black ostriches (Struthio camelus var. domesticus) of seven months old and 70-75 kg liveweight were fitted with harnesses with a canvas bag attached to it for collection of excreta and individually housed in metabolism crates, as described by Cilliers et al. (1994, 1997, 1998, 1999).

Sugar cane molasses $(75.5 \mathrm{~g} / \mathrm{kg}$ crude protein) was used in combination with a basal diet consisting of $50 \%$ locally produced lucerne hay (hammermilled through a $12 \mathrm{~mm}$ sieve; $17.5 \mathrm{~g} / \mathrm{kg}$ crude protein) and $50 \%$ yellow maize meal $(84 \mathrm{~g} / \mathrm{kg}$ crude protein). For the proportional estimation of the energy value of molasses from the basal diet ostriches were randomly divided in three groups of eight birds. Group one was fed the basal diet, group two a combination of $25 \%$ molasses and $75 \%$ basal and group three $50 \%$ molasses and $50 \%$ basal. Diets were cold pellet ( $6 \mathrm{~mm}$ sieve) to minimise wastage. Daily intakes were restricted to 1500,1800 and $2100 \mathrm{~g} / \mathrm{bird}$ to enable an extended range of encrgy intakes to be tested by regression analyses. Ostriches had access to water at all times and no health problems were found over the test periods. Spilled food was quantitatively collected on trays below the crate floors. Bags were emptied four times a day in order to prevent losses. Feed intake and excreta output were measured over five days after an adaptation period of seven days on experimental diets.

Excreta were dried in an forced draft oven at $80^{\circ} \mathrm{C}$ to constant weight, whereafter daily collection of individually ostriches were pooled over days. Gross energy (GE) was determined in a solid state bomb calorimeter and nitrogen $(\mathrm{N})$ by the standard macro-Kjeldahl method (AOAC, 1990). All results were expressed on an air dry basis.

Apparent metabolisable energy (AME) values of molasses were determined for each inclusion level by the replacement method (Hill et al., 1960). The true metabolisable energy (TME) value was determined by multiple regression as described by Cilliers et al. (1994, 1997, 1998, 1999). The slope of the model relating energy excreted $(y)$ as a function to the congruent energy intake $(x)$ yields an estimate for the unmetabolisable proportion of the diet, thus the complement of the slope (1-b), multiplied by the combustible energy value of the diet, calculate

\footnotetext{
' The average chemical composition of standard molasses (average of 19 South African Sugar Mills, according to Van Niekerk, 1991) on $75 \%$ DM is: $(\mathrm{g} / \mathrm{kg})$ moisture, 250; crude protein, 5; ether extract, 1; crude fibrc, 0; total ash, 115; nitrogen-free extractives, 584; sucrose, 332: total sugars, 467; starch, 1.7; Ca, 8.8; P, 0.7; Na, 1.6; Cl, 21.1; Mg, 5.4; K, 33.3; S, 6.8; (mg/kg) Cu, 2.2; $\mathrm{Zn}$, $2.7 ; \mathrm{J}, 101 ; \mathrm{Co}, 3.8 ; \mathrm{Mn}, 91$
} 
the TME value of the experimental diet. This is also valid in determining of dry matter digestibility (DMD) and $\mathrm{N}$-retention. $\mathrm{ME}$ values were corrected to $\mathrm{N}$-equilibrium (when nitrogen retention is zero) by the $\mathrm{N}$-retention correction factor (Wolynetz and Sibbald, 1984), as described by Cilliers et al. (1998). The standard error of $\mathrm{AME}_{\mathrm{N}}$ and $\mathrm{TME}_{\mathrm{N}}$ were calculated as described by Cilliers et al. (1994).

\section{RESULTS AND DISCUSSION}

A significant higher $\left(\mathrm{t}_{14}=1.426\right) \mathrm{AME}_{\mathrm{N}}$ value of $8.04 \pm 0.760 \mathrm{MJ} / \mathrm{kg}$ at molasses inclusion of $25 \%$ in comparison to a value of $6.79 \pm 0.443 \mathrm{MJ} / \mathrm{kg}$ at $50 \%$ inclusion have been found. Intercepts and slopes of regression lines relating feed, energy and $\mathrm{N}$ excreted $(\mathrm{y})$ to feed, energy and $\mathrm{N}$ intake $(\mathrm{x})$ in order to calculate DMD

TABLE 1

Intercepts and slopes (means \pm standard error) of regression lines relating excreta and energy output (y) to feed and energy intake $(x)$

\begin{tabular}{lccc}
\hline & Energy balance & DM digestibility & N-balance \\
\hline Intercept & $-0.062^{*} \pm 0.562$ & $0.064^{*} \pm 0.046$ & $3.970^{*} \pm 2.589$ \\
Slope $b_{1}$ for basal & $0.235 \pm 0.027$ & $0.213 \pm 0.041$ & $0.339 \pm 0.084$ \\
Slope $b_{2}$ for molasse & $0.47 \pm 0.039$ & $0.353 \pm 0.032$ & $0.318 \pm 0.151$ \\
$\mathrm{r}^{2}$ & 0.8861 & 0.8803 & 0.7230 \\
\hline
\end{tabular}

* - timates do not differ from zero $(\mathrm{P}>0.05)$

TABLE 2

True metabolisable energy values, corrected for nitrogen retention $\left(\mathrm{TME}_{\mathrm{N}}\right.$ ) of several commonly used fecdstuffs evaluated with ostriches (Cillicrs et al., 1997, 1999)

$\mathrm{TME}_{\mathrm{v}}$

$(\mathrm{MJ} / \mathrm{kg}$ on an air dry basis)

\begin{tabular}{lr} 
Cereals & \\
barley & 13.92 \\
maize & 15.22 \\
oats & 12.27 \\
sweet lupins (Lupinus albus cv Buttercup) & 14.61 \\
$\quad$ triticale & 13.21 \\
Protcin sources & 15.13 \\
$\quad$ fish meal (46\% crude protein) & 13.44 \\
$\quad$ soyabean oil cake meal & 10.79 \\
$\quad$ sunflower oil cake meal & \\
Roughages & 8.67 \\
$\quad$ common reed (Phragmites australis) & 8.59 \\
lucerne & 7.09 \\
saltbush (Atriplex nummularia) & 11.91 \\
By-products & \\
$\quad$ wheat bran & \\
\hline
\end{tabular}


digestibility, energy and $\mathrm{N}$ balance are presented in Table 1. These slopes represent the indigestible feed, unmetabolisable energy and unretainable $\mathrm{N}$ fractions of molasses. Although not forced through the origin, all slopes are non significant, indicating no apparent endogenous energy losses. A TME $\mathrm{F}_{\mathrm{N}}$ value of $7.77 \pm 0.585$ over all inclusion and feeding levels was found. Values of $9.8 \mathrm{MJ} / \mathrm{kg}$ for pigs and $8.3 \mathrm{MJ} / \mathrm{kg}$ for poultry on a $75 \% \mathrm{DM}$ basis were summarised for molasses (Van Nickerk, 1981). However, for ruminants values differ substantially, probably associated with the level of molasses fed.

The energy value of molasses determined in the present study could be added to the list of feedstuffs already evaluated for ostriches (Table 2) and use in the formulating of diets for ostriches.

\section{REFERENCES}

AOAC, 1990. Official Methods of Analysis. 15th Edition. Arlington, VA: Association of Official Analytical Chemists

Cilliers S.C., Hayes J.P, Maritz J.S., Chwalibog A., Du Pree z J.J., 1994. True and apparent metabolizable energy values of lucerne and yellow maize in adult roosters and mature ostriches (Struthio camelus). Anim. Prod. 59, 309-313

Cilliers S.C., Hayes J.P, Chwalibog A., Du Preez, J.J., Sales J., 1997. A comparative study between mature ostriches (Struthio camelus) and adult cockerels with respect to true and apparent metabolizable energy values for maize, barley, oats and triticale. Brit. Poultry Sci. 38, 96-100

Cilliers S.C., Hayes J.P., Sales J., Chwalibog A., Du Preez J.J., 1998. A comparison of metabolisable energy values of lucerne and barley between young and mature ostriches. Arch. Anim. Nutr. $51,77-82$

Cillicrs S.C., Sales J., Hayes J.P., Chwatibog A., Du Preez J.J., 1999. Comparison of metabolisable energy values of different feedstuffs determined in ostriches and poultry. Brit. Poultry Sci. (in press)

Hill F.W., Anderson D.L., Renner R., Carew L.B., 1960. Studies on the metabolizable energy of grain and grain products for chickens. Poultry Sci. 39. 573-579

Van Nickerk B.D.H, 1981. Byproducts of the sugar industry as animal feeds. S.Afr. J. Anim. Sci.11, 119-137

Wolynetz M.S., Sibbald I.R., 1984. Relationships between apparent and true metabolizable energy and the effects of a nitrogen correction. Poultry Sci, 63, 1386-1399

\section{STRESZCZENIE}

\section{Wartość energii metaboličnej melasy dla strusi}

Wartość energii metabolicznej melasy oznaczono w doświadezeniu bilansowym na 7 ośmiomiesięcznych strusiach. Obliczona rzeczywista wartość energii metabolicznej, po uwzględnieniu poprawki na zerowy bilans azotu $\left(\mathrm{TME}_{\mathrm{N}}\right)$, wynosiła $7.77 \mathrm{MJ} / \mathrm{kg}$ powietrznie suchej masy melasy, podczas gdy odpowiednie dane podawane w literaturze wynoszą dla drobiu 8,3 , a dla świni $9,8 \mathrm{MJ} / \mathrm{kg}$ melasy o zawartości $75 \%$ s.m. Wydaje się, że poziom melasy w diecic możc mieć, podobnie jak u przeżuwaczy, wpływ na jej wartość energetyczną. Oznaczona wartość energetyczna melasy może uzupcłnić listę pasz w tabclach wartości pokarmowcj pasz dla strusi. 